\title{
A research on the variables that effect affective commitment to change
}

\author{
Değişime duygusal bağlılığa etki eden değişkenler üzerine bir \\ araştırma
}

\author{
Mehmet Ertem ${ }^{1}$ \\ Faruk Kerem Şentürk²
}

\begin{abstract}
${ }^{1}$ Dr. Öğr. Üyesi, Yozgat Bozok Üniversitesi, Yozgat, Türkiye, Mehmet.ertem@bozok.edu.tr
\end{abstract}

ORCID: 0000-0001-9350-4379

2 Doç. Dr., Düzce Üniversitesi, Düzce, Türkiye, keremsenturk@duzce.edu.tr

ORCID: 0000-0002-3055-0797

\section{Corresponding Author:}

Faruk Kerem Şentürk,

Düzce Üniversitesi, Düzce, Türkiye, keremsenturk@duzce.edu.tr

Submitted: 25/01/2021

Revised: 5/03/2021

Accepted: 10/03/2021

Online Published: 25/03/2021

Citation: Ertem, M., \& Şentürk, F.K., A research on the variables that effect affective commitment to change, bmij (2021) 9 (2): 327-342, doi: https://doi.org/10.15295/bmij.v9i1.1761

\begin{abstract}
Regardless of the change process level for businesses, employees' participation in the change process is a vital factor. Change as an attempt to question the current order and replace it with a more effective and efficient system requires employees to support and see themselves as part of the process emotionally. The research conducted in this context aims to determine the factors that effect affective commitment to change (ACC). In this context, it aims to guide businesses on which factors they should focus on in their change processes. In the study, a quantitative method was preferred, a questionnaire form was used as the data collection technique, and the data were obtained from healthcare professionals working in the Yozgat Provincial Health Directorate. The results indicated that perception of change (general perception, readiness for change, and being affected by the change) and emotional deprivation have negative effects on affective commitment to change. In contrast, communion striving, teamwork, social companionship and workplace friendship have no meaningful effects on the dependent variable.
\end{abstract}

Keywords: Affective Commitment to Change, Teamwork, Workplace Friendship, Workplace Loneliness, Communion Striving

Jel Codes: D23, M10

Öz

İşletmeler için değişim sürecinin seviyesi ne olursa olsun, çalışanların değişim sürecine katılımı hayati bir faktördür. Mevcut düzeni sorgulama ve onu daha etkili ve verimli bir sistemle değiştirme girişimi olarak değişim, çalışanların duygusal olarak destek vermelerini ve kendilerini sürecin bir parçası olarak görmelerini gerektirir. Bu bağlamda yapılan araştırma, değişime duygusal bağlılığı etkileyen faktörleri belirlemeyi amaçlamaktadır. Ayrıca, işletmelere değişim süreçlerinde hangi faktörlere odaklanmaları gerektiği konusunda rehberlik etmeyi amaçlamaktadır. Araştırmada nicel yöntem tercih edilmiş ve veri toplama tekniği olarak anket formu kullanılmıştır. Veriler Yozgat İl Sağlik Müdürlügüü'nde görev yapan sağlık çalışanlarından elde edilmiştir. Sonuçlar, değişim algısının (genel alg1, değişime hazır olma ve değişimden etkilenme) ve duygusal yoksunluğun değişime duygusal bağlılık üzerinde olumsuz etkileri olduğunu, birlik olma çabası, takım çalışması ve işyeri arkadaşlı̆̆ının bağımlı değişken üzerinde anlamlı bir etkisinin olmadığını göstermiştir.

Anahtar Kelimeler: Değişime Duygusal Bağlılık, Takım Çalışması, İşyeri Arkadaşlığı, İşyerinde Yalnızlık, Birlik Olma Çabası

JEL Kodları: D23, M10 


\section{Introduction}

A reference to the concept of "change" or rapidly changing external environmental conditions can be found in the first sentence, or at least in the first paragraph, of almost every article written in the field of management and organization. Even though such statements are seen as cliché regarding management and organizational literature, they are not unfair. Because it can be said that economic, sociological and cultural change has become the primary variable that shapes the business world due to stunning developments in science and technology. In the unrelenting hyper-competition (D'aveni \& Dagnino, 2010) environment caused by this rapid change, businesses try to adapt themselves to changing environmental conditions by constantly changing and adapting themselves to survive and gain a competitive advantage over their competitors. This adaptation effort often requires businesses to go through severe and deep-seated organizational change processes (Todnem, Kuipers, \& Procter, 2018; Weick \& Quinn, 1999). At this point, it would be correct to mention how the concept of organizational change is defined. Organizational change is a concept that includes changes in the way an organization operates, who its employees and managers are, what physical and organizational structure is, and how its resources are used (Weick \& Quinn, 1999; Fjellstedt, 2015). According to Conner and Lake (1988), organizational change is the change that manifests itself in four main areas: individual tasks, organizational processes, organization's strategic decision processes/direction and organizational culture (Connor \& Lake, 1988; Wilson, 2010, p. 3).

The literature on organizational change processes, the management of these processes and the various problems encountered take an essential place in management. For many years, change management has existed in the management and organization literature as a field of expertise in itself. Organizational change literature tries to understand how change practices affect employees' attitudes and behaviours towards change (Fjellstedt, 2015; Fedor, Caldwell, \& Herold, 2006; Wanberg \& Banas, 2000; Wilson, 2010; Bovey \& Hede, 2001). Employees' behaviour towards change can be classified in different ways: strong-weak, implicit-explicit, active-passive, and supportive-resistant (Erwin \& Garman, 2010, p. 42). For this study, the main distinction is made in resisting and supporting change (Armenakis, Harris, \& Mossholder, 1993, p. 681-682) whether employees support change or not is essentially a matter of how employees perceive change (positively or negatively), how ready they are for change and their level of commitment to the change process.

Enterprises trying to adapt to changing environmental conditions inevitably undergo sudden and/or radical organizational change processes at least several times in their life course. Throughout these processes, every top manager desire that all employees accept the organizational change process and that in the organisation, everyone contributes sincerely to the process, but the situation rarely develops in this way (Weick \& Quinn, 1999; Shum, Bove, \& Auh, 2008; Wilson, 2010). For all employees, especially those in the middle and lower ranks, change is scary, and employees rarely perceive change positively (Coch \& French, 1948). Significant organizational changes are often initiated and managed by the top management, so there is no option for employees at lower levels other than keeping up with the process. Employees can be expected to be negatively affected by a change process that they perceive negatively and cannot predict their courses and results (Bovey \& Hede, 2001). Relevant literature looks at organizational change processes in top management and those who manage change (Isabella, 1990; Armenakis, Harris, \& Mossholder, 1993). In this way, it is impossible to come across studies that focus on employees' role in the organization and the social interactions in a change process initiated and maintained from top to bottom.

In this study, the concept of commitment to change means that employees fondly and willingly support and contribute to the change process. The research was carried out on health sector employees, as they have been affected by the recent structural and technological change processes. Altındiş et al. (2011) emphasize in their study that the resistance perception of health professionals toward organizational change is at an average level, risk perception of health professionals toward organizational change is average, and their emotional reaction perception level is high. The perception level toward support of change is low for nurses and high for medical doctors. Commitment to change is one of the most fundamental concepts in organizational change literature and theoretically builds upon the organizational commitment literature. Within the study's scope, the "commitment to change" subject will be examined in terms of the negative perception of change (perception of change, readiness for change and being affected by the change), communion striving, teamwork, workplace friendship and workplace loneliness. Identifying the variables that affect commitment to change will benefit health sector managers and employees involved in radical change processes to manage the process successfully. It also aims to emphasize the necessity to consider the change processes based on the 
employee and address the employees' psychological and emotional aspects in the context of their adaptation to the process.

\section{Literature review}

In this section, affective commitment to change, negative perception of change, communion striving, teamwork (participative safety), workplace friendship, loneliness in the workplace subjects are discussed.

\section{Affective commitment to change}

Organizational commitment defined as "the relative strength of an individual's identification with and involvement in a particular organization" (Mowday, Steers, \& Porter, 1979, p. 226; Herscovitch \& Meyer, 2002). There are essentially three primary factors when talking about commitment (Mowday, Steers, \& Porter, 1979, p. 226): (1) a strong belief in and acceptance of the organization's goals and values, (2) a willingness to exert considerable effort on behalf of the organization, (3) a strong desire to maintain membership in the organization. According to these definitions, commitment to change is defined as "a power, a way of thinking or a mindset that connects individuals to the behavioural patterns necessary for the change to be successful encourages them to show these behaviours, and enables them to participate actively in the change process" (Herscovitch \& Meyer, 2002, p. 475). This type of mindset can be reflected in three different ways, (1) effective, (2) continuance, and (3) normative, in line with the dimensions of organizational commitment. An individual who has an effective commitment to change will have an emotional desire, a passion for supporting the change process (Shum, Bove, \& Auh, 2008). In continuation commitment, the individual tends to support the change process as he is aware of the cost of not supporting change (material or moral). On the other hand, an individual who has a normative commitment to change feels obliged to support change with a sense of debt (Meyer \& Allen, 1997; Herscovitch \& Meyer, 2002).

In the relevant literature, individuals' attitudes and behaviours towards organizational change are positive and negative. Employees' positive or negative behaviours in the face of change are examined in line with the concept of "commitment to change", which is shaped by the theory of "Organizational Commitment" in the relevant literature (Meyer \& Allen, 1997; Mowday, Steers, \& Porter, 1979). Commitment to change can be defined as "the force that pushes the individual to exhibit an attitude and behaviour that supports the change process" (Herscovitch \& Meyer, 2002). An employee committed to change develops a positive attitude towards change, while another employee with a weak sense of commitment is possible to demonstrate a behaviour oppose the change (Shum, Bove, \& Auh, 2008). Whether or not to show commitment to change is shaped under the influence of certain factors. First of all, the issue of how and to what extent employees are affected by the change is a situation that determines the attitude or behaviour towards change because an employee may not take a positive or negative position in the face of a change process that does not affect him.

On the other hand, how the employee perceives the change process can be considered one of the determining factors (Weick \& Quinn, 1999). To what extent is an employee who perceives the change process negatively positively and behaves positively in the process? Similarly, an employee who does not perceive himself as ready for this change process is not considered a positive perception of the change process. In this direction, this research empirically examines the relationship between employees' commitment to change and their negative perceptions of change, their readiness for change, and their harmful exposure to change.

On the other hand, the relevant literature looks at change management, attitudes, and behaviour towards change from a change agent/manager's perspective. As a natural result of this situation, interpersonal relationships on adherence to change have not attracted much attention in the relevant literature. However, a change process that profoundly affects the way the organization is affiliated and carried out from above (initiated and managed by the top management) will also affect the organization's sociological structure, specifically the formal and informal relations between individuals and team dynamics.

\section{The negative perception of change}

It has been previously stated that the continuous and rapid changes in the technological and sociocultural environment push organizations to adapt themselves to this change, and therefore organizational change has become a necessity how employees perceive these changes and how they develop attitudes towards these changes are also the main factors affecting organizational change processes' success. Also, it has been previously stated that the concept of commitment to change, which is one of the variables of this research, is located at the positive end of a hypothetical scale of employees' 
positions against change. The opposing end of the same scale also has resistance to change. Just like a commitment to change, the behaviour of resisting change is examined in three dimensions: emotional, behavioural and cognitive (Rafferty \& Jimmieson, 2017). Organizational change processes have an emotional aspect and can affect employees at all levels within the organization in very radical and compelling ways. These effects of change cause a reaction in employees too. Employees' negative perception of change and, therefore, negative feelings and attitudes towards it also arise as a result of being negatively affected by the chaos and setbacks brought about by the change and stress experienced due to these negativities (Rafferty \& Jimmieson, 2017; Huy, 2002; Tavakoli, 2014). Employees' negative perceptions of change may result in a low level of commitment to an organizational change in their business. The hypothesis created in line with all this information is as follows:

$\mathrm{H1}_{\mathrm{a}}$ : A negative perception of change has a negative and significant effect on affective commitment to change.

On the other side, almost every organizational change process brings uncertainty, confusion or disruptions for employees. However, some may perceive and show commitment positively among these employees, while others may be inclined to resist change (Bovey \& Hede, 2001; Erwin \& Garman, 2010). One of the factors that cause the difference in organizational change perceptions is the differing levels of employees' readiness for change. In other words, it can be predicted that employees who feel ready for change will tend to support change, while some other employees who are caught unprepared for change will be able to resist change (Armenakis, Harris, \& Mossholder, 1993). It is also possible that some employees are not affected by the change process, unlike others. In such a case, it may be expected that employees will not develop a positive or negative attitude towards change. The hypothesis created in line with all this information is as follows:

$\mathrm{H1}_{\mathrm{b}}$ : A negative perception of readiness for change has a negative and significant effect on affective commitment to change.

H1: A negative perception of being affected by change has a negative and significant effect on affective commitment to change.

\section{Communion striving}

The concept of communion striving is frequently discussed in the relevant literature about the "Agreeableness" concept, one of the Big Five Personality Traits. (Barrick, Stewart, \& Piotrowski, 2002). Communion striving is one of the three main trends that are shaped on the basis of the personalities of individuals in business life. It encourages them to develop social interaction, together with the motivation of the status striving and accomplishment striving (Wiggins \& Trapnell, 1996; Hogan \& Shelton, 1998). Simply, communion striving means the motivation to strive to be accepted by other people and get along with them. This effort is not a tendency seen at the same rate in all people because being loved and accepted by the social structure may not be so important for everyone (Barrick, Stewart, \& Piotrowski, 2002). Individuals with high motivation for the communion striving, in order to be accepted by the social environment they are in, show behaviours and characteristics such as warmbloodedness, understanding, respect, interoperability, which will make them a more harmonious person or make them understood in this way by others (Ng \& Lucianetti, 2015; Abele \& Wojciszke, 2007). As a result, an employee with high motivation for the communion striving will show a higher level of commitment to change in a change process initiated by top management and supported by a significant number of employees in that enterprise. It would be meaningful to think that there may be a lower level of commitment to change in a change process that is not approved by most of the business. The hypothesis created in line with all this information is as follows:

\section{H2. Perception of communion striving has a positive and significant effect on affective commitment} to change.

\section{Teamwork (participative safety)}

Competition conditions, which are getting more challenging due to rapidly changing external and internal environmental conditions, reduce the work rate that a person can do adequately in organizations day by day. The reason for this is that the tasks that must be fulfilled for organizations to survive in an increasingly tricky competition environment have become duties that require expertise in more than one field and exceed one person's capacity in terms of workload. On the other hand, due to the need to adapt rapidly and accurately to the increasingly accelerating change, large task groups with a crowded and multi-layered hierarchical structure remain cumbersome. This has led organizations to set up small task groups/teams that are not as rigid and cumbersome as crowded task groups, and that can also perform tasks that no one employee can handle due to the needs of experts in more than one 
field (Bell, 2007, p. 595; Devine, Clayton, Philips, Dunford, \& Melner, 1999; Campion, Medsker, \& Higgs, 1993). Teams are structures where experience regarding methods and processes is created and shared, facilitates access to knowledge to various organizational levels, and ensures that their members participate in decision and planning processes. In this way, the loyalty and synergy between the team members will be increased, and thus goals can be reached faster and easier (Y1lmaz, 1999; Ergün \& Eyisoy, 2018).

It is possible to come across many definitions regarding the concept of "team" in the relevant literature. A team can be defined as social structures where more than one person works together for a common purpose. Straub (2002) defines it as a community of members with shared values who come together for common interests to achieve specific goals. The teams' members focus on the same goal and take responsibility for this purpose as a partner and complement each other (Straub, 2002). More specifically, the team is a social unit that is independent in its tasks, bears joint responsibility for the resulting outputs, sees itself as a social unit that is integrated into one or more social structures (for example, a business or a company) and is perceived from the outside. Also, it is a community of people who manage their relations within organizational boundaries (Todnem, Kuipers, \& Procter, 2018; Cohen \& Bailey, 1997). Guzzo and Dickson (1996) defines the concept of a team as "a social entity created by individuals who are externally seen as members of the same social group, have a common purpose and work as parts of a whole".

Businesses may prefer team-based work practices for different reasons, such as the change in the environment requires team skills, taking advantage of the multiplier effect of team synergy, increasing organisational efficiency, individual motivation, creativity and productivity, and increasing the sense of commitment within the organisation (Hakanen \& Häkkinen, 2015). Naturally, the most important one among these reasons for this research study is the concept of "commitment". Teams and the concept of commitment are often used together in the relevant literature (Shum, Bove, \& Auh, 2008, p. 1360; Ghorbanhosseini, 2013; Nohe, Michaelis, Menges, Zhang, \& Sonntag, 2013; Anderson \& West, 1998). It is known that teams and team-based work have positive effects on commitment. According to Nohe et al. (2013), the high level of commitment of the team's individuals causes an increase in each individual's performance and the motivation of the other team members, increasing collective performance, thus increasing the team performance. Also, this mechanism works in reverse. In other words, whether an employee group can be a team or not is a matter of whether the individuals constitute that group feel loyal to the team and their teammates (Baker, Day, \& Salas, 2006, p. 1579). On the other hand, the concept of trust, which we have included in the field research, is also evaluated in this study about the concept of teams and commitment (to change). Trust in interpersonal relations and participation processes within the team is an important phenomenon that can be considered a prerequisite for team members to feel loyal to their teammates. The team members' trust in each other and the team may affect team performance and team members' commitment to the team and, therefore, to the change process because the performance and productivity of an employee who does not trust the other members of the team and the team leader may decrease (De Jong \& Elfring, 2010, p. 535-536). In this context, commitment to individual change and team members' trust in each other are evaluated about team performance. The hypothesis created in line with all this information is as follows:

\section{H3. Perception of participative safety has a positive and significant effect on affective commitment to change.}

\section{Workplace friendship}

It can be easily observed in real life and in the relevant literature that a significant part of interpersonal relationships in the organizational field consist of informal relationships. Workplace friendship is also an essential part of the informal relationships between individuals within the organization. Despite the relative scarcity of studies in the field, it is a fact that can easily be observed how important workplace friendship is for employees and businesses.

Workplace friendship is defined as employees' interaction with each other inside and outside the workplace (Nielsen, Jex, \& Adams, 2000; Özbek, 2018). These interactions can develop between employees at the same hierarchical level, between subordinate and senior employees, or between employees from different departments (Berman, West, \& RichterJr., 2002). According to another definition, workplace friendship is an interpersonal relationship that involves mutual closeness between two or more individuals. Individuals who are parties of this relationship can set common goals and values and act by them (Huang, 2016; Biçer \& Büyükyılmaz, 2019).

Workplace friendship is a personal and informal form of relationship. This kind of relationship cannot be planned, and it is wholly based on the volunteerism of individuals (Berman, West, \& RichterJr., 2002). 
Workplace friendship is a voluntary and holistic relationship, and it differs from other forms of relationship in the workplace with these features. The workplace friendship is a voluntary connection is since it is a relationship that two colleagues have built and developed willingly, by giving effort and time, without any formal necessity. The holistic nature of this relationship means that the parties perceive each other as a whole person, with their total assets inside and outside the workplace (Morrison \& Cooper-Thomas, 2015; Sias, Smith, \& Avdeyeva, 2009).

Workplace friendship is a concept that has attracted the attention of two essential social sciences areas, psychology and management. There are two main reasons why these areas tend to focus on workplace friendship. First, workplaces constitute a small observable area in terms of social sciences and appear to be a social environment where individuals have limited options for developing social relationships, but where they can relate to a limited number of people in their narrow surroundings. The second reason is that workplace friendship is in a positive relationship with organizational facts such as job satisfaction, employee turnover, organizational commitment, creativity and job performance, which are considered essential for organizations and their managers (Berman, West, \& RichterJr., 2002; Nielsen, Jex, \& Adams, 2000; Özbek, 2018; Morrison \& Cooper-Thomas, 2015). In this context, this study also addresses the relationship of workplace friendship as a dependent variable with affective commitment to change. The hypothesis created in line with all this information is as follows:

\section{H4. Perception of workplace friendship has a positive and significant effect on affective commitment to change.}

\section{Loneliness in the workplace}

The human is a social being and needs to establish meaningful and regular relationships with other people around him, but he may not always be able to meet this need, and in this case, he experiences a feeling of loneliness. Loneliness is a widespread and severe emotion that can be described as a psychological condition (Perlman \& Peplau, 1981) resulting from qualitative or quantitative deficiencies in an individual's social relationships. Many different definitions of the concept of loneliness have been made as a subject focused by researchers from many different fields such as psychology, sociology, social psychology, and organizational behaviour. Marangoni and Ickes (1989) found that these different definitions have three essential common points. First of all, (1) loneliness is a personal subjective experience and may not always mean social isolation. (2) This experience is an undesirable, distressing situation for the individual who experiences it, and (3) this is caused by certain social relationship deficiencies experienced by individuals (Marangoni \& Ickes, 1989, p. 93).

Every person experiences the feeling of loneliness at some point in their life. The feeling of loneliness is often thought to be a selfish pursuit of people who cannot establish interpersonal relationships and who are shy about social relationships. The relevant literature says that this is not the case most of the time. Studies have found that people who experience a sense of loneliness are often not simply self-centred or incapable of real social bonding (Marangoni \& Ickes, 1989; Green \& Wildermuth, 1993). In other words, the person may feel lonely when there are many people around and may not experience loneliness as a feeling even though there are not many people around.

Wright, Burt and Strongman (2006), in their study, in which they developed the scale of loneliness in business life, argue that the concept of loneliness in business life has two dimensions, mainly social and emotional. The emotional dimension is related to the feelings of loneliness experienced by the employees, while the social dimension is related to whether they are alone (Wright et al., 2006). Therefore, it would not be wrong to assume a relationship between the emotional dimension of loneliness and the affective commitment to change. In the relevant literature, no study has been found that deals directly with the concept of affective commitment to change and workplace loneliness. However, some studies directly or indirectly touch on the relationship between the concept of organizational commitment and workplace loneliness (Wright, 2005, p. 48; Ertosun \& Erdil, 2013; Ayazlar \& Güzel, 2014). As a result, examining the relationship between workplace loneliness and affective commitment to change is considered significant. The hypothesis created in line with all this information is as follows:

H5. Emotional deprivation, one of the dimensions of loneliness in the workplace, has a negative and significant effect on emotional commitment to change.

$\mathrm{H}_{5}$. Social companionship, one of the dimensions of loneliness in the workplace, has a negative and significant effect on emotional commitment to change. 


\section{Methodology}

The quantitative method was preferred in terms of the route followed in the study. The questionnaire was used as the data collection technique. The questionnaire is a method of obtaining data by responding to questions created in a predetermined order and structure (Altunışık, Coşkun, Bayraktaroğlu \& Yıldırım, 2007, p. 68). Information about the population and sample, data collection tools, and research model is shared under this heading.

\section{Population and sampling}

The study population consisted of a total of 372 staff affiliated with the Yozgat Provincial Health Directorate. The sampling method was used, and to calculate the number of samples, " $n=$ N.t².p.q / $\mathrm{d}^{2} .(\mathrm{N}-1)+\mathrm{t} . p . \mathrm{q}^{\prime \prime}$ formula was applied (Karagöz, 2014) and the number to be reached was determined as 190. The convenience sampling method was used to obtain data. A total of 250 questionnaires were distributed, 216 questionnaires were collected, 11 questionnaires were eliminated due to missing data and the research was carried out on 205 questionnaires. The data obtained within the scope of the research were collected between 20 October 20 December 2019.

\section{Data collection tools used in the study}

\section{Affective commitment to change the scale}

The scale developed by Herscovitch and Meyer (2002) was used to measure commitment to change. The scale has three sub-dimensions consisting of 18 items; in the research, affective commitment to change sub-dimension, which has six items, was used. The scale was adapted to Turkish by Toprak and Aydin (2015) has six items.

\section{The negative perception of change scale}

The scale developed by Herscovitch (2003) was used to measure the negative perception of change. The Turkish version of the scale was used by Seçkin, Demirel \& Özçınar (2016). The scale consists of six subdimensions (perception of change, readiness for change, feeling of change, being affected by the change, and resistance to change) with 71 items. Within the scope of the research, sub-dimensions of perception of change ( 8 items), readiness for change ( 7 items) and being affected by the change $(7$ items) were used.

\section{Communion striving scale}

The scale developed by Barrick et al. (2002) was used to measure the perception of communion striving. The scale consisted of nine items under one dimension. The scale was adapted to Turkish by Iliyas (2016).

\section{Teamwork scale (participative safety) scale}

The teamwork scale was developed by Anderson and West (1998) in a 5-dimensional structure. The scale was adapted to Turkish by Işık (2014), and the researcher handled two dimensions in the original scale in his study. Within the research scope, the participative safety dimension with five items was used in the research.

\section{Workplace friendship scale}

The workplace friendship scale was developed by Nielsen et al. (2000) as 12 items in a two-dimensional structure. The scale was adapted to Turkish by Çalışkan (2011) by considering only six workplace friendship dimensions. At the end of the validity study, the researcher revealed that the scale is represented in Turkish with five items.

\section{Loneliness in the workplace scale}

Loneliness in the workplace scale was developed by Wright et al. (2006) as 16 items in two subdimensions named emotional deprivation and social companionship. The scale was adapted to Turkish by Doğan et al. (2009) as two sub-dimensions and 16 items similar to the original scale.

\section{Reliability of the scales used in research}

The data of the researchers who developed the scale and adapted it into Turkish are shown in Table $x$ together with Cronbach Alpha coefficients, means and standard deviations of dimensions. 
Table 1: Descriptive Statistics \& Cronbach Alfa Scores

\begin{tabular}{l} 
Variables \\
\cline { 5 - 9 }
\end{tabular}

Hair et al. (2010) and Bryne (2010) argued that data is considered to be expected if skewness is between -2 to +2 and kurtosis is between -7 to +7 . It is seen that kurtosis and skewness values of the variables are within the threshold value ranges. An acceptable Cronbach's alpha reliability coefficient is expected to be 0.70 and above (Ural \& Kılıç, 2005, p. 258; Altunışık, Coşkun, Bayraktaroğlu \& Yıldırım, 2015, p. 126). The scores obtained reveal that the scales are generally reliable. The score of .53 was obtained due to the reliability analysis of the analysis conducted for the social companionship dimension in the loneliness in the workplace scale; after the 14th item is removed, the result of the analysis performed again is stated in the table. However, it can be seen that the perception of readiness for change dimension has a lowreliability score (Yıldız \& Uzunsakal, 2018, p. 19). On the other hand, when the variable is considered as a whole with other dimensions, it can be said that the overall reliability is reliable. When the means are evaluated, it is seen that affective commitment to change is moderate; other positive dimensions are above the moderate and negative dimensions below the moderate.

\section{Research model and hypothesis}

The study's scope aims to explain the affective commitment to change, which is the dependent variable, with the negative perception of change, workplace friendship, loneliness in the workplace, participation and trust in teamwork, and communion striving. In this context, models and hypotheses supported by the literature review are as follows.

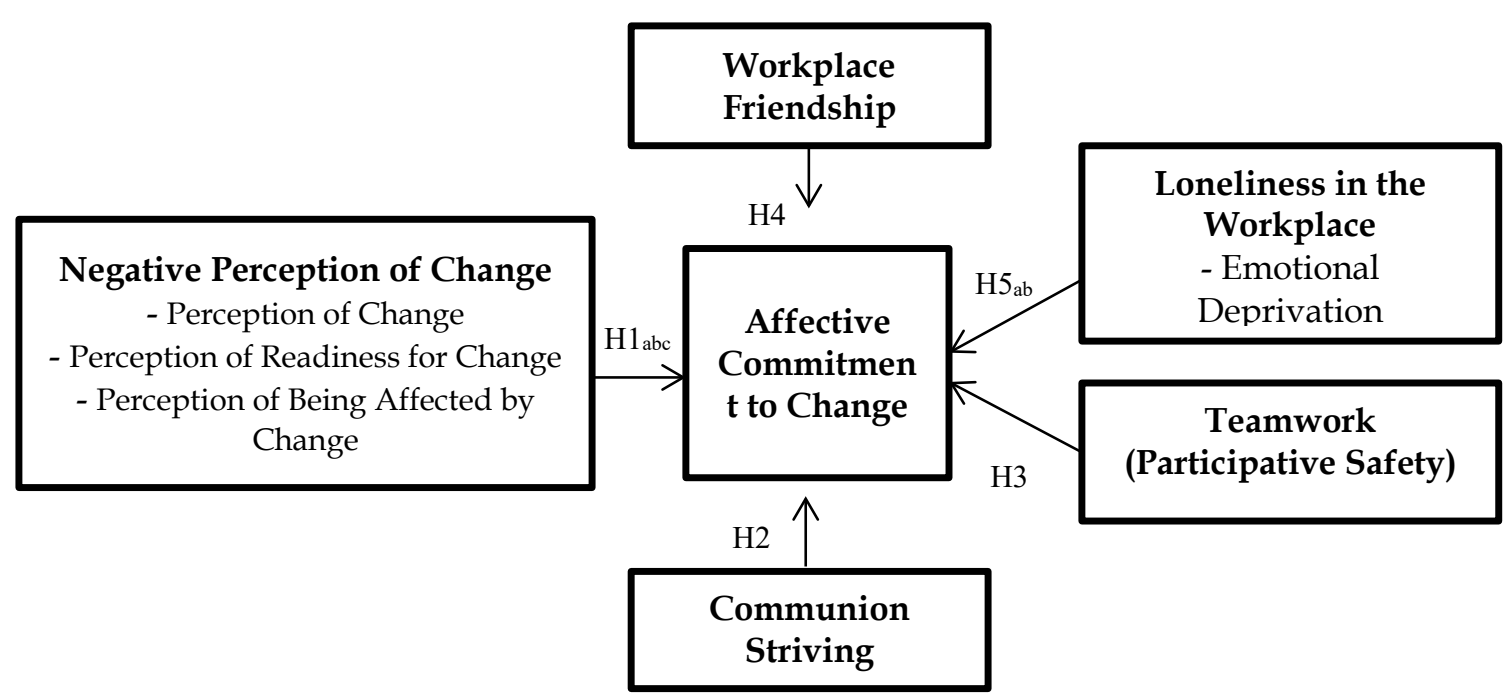

Figure 1: The research model of the study 


\section{Results}

Under this heading, the findings of the regression analysis performed for the hypothesis tests are shared.

\section{Regression analysis results}

In this part of the study, regression analyses conducted to determine the interactions between the dependent variable of the study - affective commitment to change - and independent variables are shared.

Table 2: Negative Perception of Change and Affective Commitment to Change

\begin{tabular}{l|c|c|c|c|c|c|c|c|c}
\hline Variable & $\mathbf{B}$ & Std. Error & $\boldsymbol{\beta}$ & $\mathbf{t}$ & $\mathbf{p}$ & $\begin{array}{l}\text { Paired } \\
\mathbf{r}\end{array}$ & Partial r & Tol. & VIF \\
\hline (Constant) & 5,146 &, 223 & & 23,047 & .000 & & & & \\
\hline Perception of Change &,- 320 &, 063 &,- 381 & $-5,092$ &, 000 &,- 563 &,- 347 &, 597 & 1,675 \\
\hline Perception of Readiness for Change &,- 247 &, 086 &,- 195 & $-2,874$ &, 005 &,- 446 &,- 205 &, 728 & 1,373 \\
\hline Perception of Being Affected by Change &,- 136 &, 065 &,- 150 & $-2,103$ &, 037 &, 447 &,- 151 &, 654 & 1,528 \\
\hline
\end{tabular}

Dependent Variable: Affective Commitment to Change

R:,607 $\quad \mathbf{R}^{2}:, 368 \quad$ F:36,744 p: ,000 Durbin-Watson:1,930

Table 2 shows the regression analyses results of the negative perception of change and ACC. In line with the results of the regression analysis, when the paired and partial correlations between the independent variables and the dependent variable are examined, it is seen that there are negative relationships between the variables. Then, when the VIF values are considered, it is understood that the variables do not have a value higher than ten, and the tolerance values are not less than 0.20. Furthermore, the Durbin-Watson coefficient of 1,930, which is required to be between $0-4$, indicates no problematic relationship between independent variables and error terms.

According to the findings in Table 2, the level of explanation of the dependent variable $\left(0 \leq R^{2} \geq 1\right)$ based on independent variables is statistically significant ( $R^{2}: 368$, F: 36.744, p: 000). When the standardized regression coefficients $(\beta)$ are considered, the relative significance of the variables on affective commitment to change can be aligned with the perception of change, perception of readiness for change, and perception of being affected by the change. When the results of the t-test regarding the significance of regression coefficients were examined, it was understood that independent variables have a significant and negative effect on affective commitment to change. Based on these findings, the $\mathrm{H}_{\mathrm{a}}, \mathrm{H} 1_{\mathrm{b}}$ and $\mathrm{H} 1_{\mathrm{c}}$ hypotheses are accepted.

Table 3: Communion Striving and Affective Commitment to Change

\begin{tabular}{l|c|c|c|c|c}
\hline Variable & $\mathbf{B}$ & Std. Error & $\boldsymbol{\beta}$ & $\mathbf{t}$ & $\mathbf{p}$ \\
\hline (Constant) & 2,790 &, 299 & & 9,330 & .000 \\
\hline Communion Striving &, 120 &, 084 &, 102 & 1,421 &, 157 \\
\hline
\end{tabular}

Dependent Variable: Affective Commitment to Change

$\mathbf{R}:, 102 \quad \mathbf{R}^{2}:$, 010 $\quad$ F:2,021 p: ,157 Durbin-Watson:1,702

According to the findings in Table 3, the level of explanation of the dependent variable $\left(0 \leq R^{2} \geq 1\right)$ based on independent variables is statistically not significant ( $R^{2}$ : ,010 F: 2.021, p: 157). When the results of the $\mathrm{t}$-test regarding the significance of regression coefficients were examined, it was understood that the independent variable does not have a significant effect on affective commitment to change. Based on these findings, the $\mathrm{H} 2$ hypothesis is rejected. 
Table 4: Teamwork (Participative Safety) and Affective Commitment to Change

\begin{tabular}{l|c|c|c|c|c}
\hline Variable & $\mathbf{B}$ & Std. Error & $\boldsymbol{\beta}$ & $\mathbf{t}$ & $\mathbf{p}$ \\
\hline (Constant) & 2,816 &, 274 & & 10,280 & .000 \\
\hline Participative Safety &, 103 &, 071 &, 105 & 1,462 &, 145 \\
\hline
\end{tabular}

Dependent Variable: Affective Commitment to Change

\section{$\mathbf{R}:, 105 \quad \mathbf{R}^{2}:, 011 \quad$ F:2,137 $\quad$ p: ,145 $\quad$ Durbin-Watson:1,717}

According to the findings in Table 4 , the level of explanation of the dependent variable $\left(0 \leq R^{2} \geq 1\right)$ based on independent variables is statistically not significant ( $\left.R^{2}:, 011 \mathrm{~F}: 2.137, \mathrm{p}: 145\right)$. When the results of the $\mathrm{t}$-test regarding the significance of regression coefficients were examined, it was understood that the independent variable does not have a significant effect on affective commitment to change. Based on these findings, the $\mathrm{H} 3$ hypothesis is rejected.

Table 5: Workplace Friendship and Affective Commitment to Change

\begin{tabular}{l|c|c|c|c|c}
\hline Variable & $\mathbf{B}$ & Std. Error & $\boldsymbol{\beta}$ & $\mathbf{t}$ & $\mathbf{p}$ \\
\hline (Constant) & 3,008 &, 251 & & 12,006 & .000 \\
\hline Participative Safety &, 056 &, 068 &, 059 &, 816 &, 416 \\
\hline
\end{tabular}

Dependent Variable: Affective Commitment to Change
R:,059
$\mathbf{R}^{2}:, 003$
F:,666
p: , 416
Durbin-Watson:1,716

According to the findings in Table 5, the level of explanation of the dependent variable $\left(0 \leq R^{2} \geq 1\right)$ based on independent variables is statistically not significant ( $\left.R^{2}:, 003 \mathrm{~F}:, 666 \mathrm{p}: 416\right)$. When the results of the $\mathrm{t}$-test regarding the significance of regression coefficients were examined, it was understood that the independent variable does not have a significant effect on affective commitment to change. Based on these findings, the $\mathrm{H} 4$ hypothesis is rejected.

Table 6: Loneliness in the Workplace and Affective Commitment to Change

\begin{tabular}{l|c|c|c|c|c|c|c|c|c}
\hline Variable & $\mathbf{B}$ & Std. Error & $\boldsymbol{\beta}$ & $\mathbf{t}$ & $\mathbf{p}$ & Paired r & Partial r & Tol. & VIF \\
\hline (Constant) & 4,220 &, 278 & & 15,169 & .000 & & & & \\
\hline Emotional Deprivation &,- 325 &, 097 &,- 267 & $-3,361$ &, 000 &,- 301 &,- 237 &, 762 & 1,312 \\
\hline Social Companionship &,- 107 &, 121 &,- 070 &,- 882 &, 379 &,- 200 &,- 064 &, 762 & 1,312 \\
\hline
\end{tabular}

Dependent Variable: Affective Commitment to Change

$$
\text { R:,307 R : } \quad \text {,094 F:9,818 p: ,000 Durbin-Watson:1,725 }
$$

Table 6 shows the regression analyses results of workplace loneliness and ACC. In line with the results of the regression analysis, when the paired and partial correlations between the independent variables and the dependent variable are examined, it is seen that there are negative relationships between the variables. Then, when the VIF values are considered, it is understood that the variables do not have a value higher than 10 , and the tolerance values are not less than 0.20 . Furthermore, the Durbin-Watson coefficient of 1,725 , which is required to be between $0-4$, indicates no problematic relationship between independent variables and error terms.

According to the findings in Table 6 , the level of explanation of the dependent variable $\left(0 \leq R^{2} \geq 1\right)$ based on independent variables is statistically significant ( $\left.R^{2}: 094, F: 9.818, p: 000\right)$. When the standardized regression coefficients $(\beta)$ are considered, the relative significance of the variables on affective commitment to change can be aligned with emotional deprivation and social companionship. When the results of the t-test regarding the significance of regression coefficients were examined, it was 
understood that social companionship did not have a significant effect on affective commitment to change. In contrast, the emotional deprivation variable was seen to have a negative and significant effect on affective commitment to change. Based on these findings, while the $\mathrm{H} 5_{\mathrm{a}}$ hypothesis is accepted, the $\mathrm{H} 5_{\mathrm{b}}$ hypothesis is rejected.

\section{Conclusion and recommendations}

The embryo thrives from the moment of its conception to the mother's womb to adapt to the life conditions it will face after birth. Likewise, this development and adaptation process continues until the end of life. In this context, people sense and observe the environmental changes that will affect their lives over time, access the information they need and survive by adapting to change. There are signs of an effort to adapt to a patient's search for a cure or a stressful person's search for relaxation. Changes that require an adaptation process are not always optional, and sometimes they appear as a necessity.

The "organizational ecology" approach put forward by Hannan and Freeman (1977) focuses on the relations of the organizations in a particular society and industry or with their environment by considering the businesses as living organisms. This approach states that organizations that cannot comply with the necessary change processes from the environment will be eliminated. In particular, the time frame we are in pushes organizations to consider information and technology-based changes in their output rather than physical elements and switch to knowledge-based competition (Koçel, 2005).

Change, by its nature, can affect organizations at different levels and in various areas. These processes, which are generally seen in the area of influence and responsibility of the top management, require the employees' active and voluntary participation. In order to ensure the aforementioned participation, it is essential to define the variables that affect this process and to determine their effect levels. The negative perception of change, communion striving, teamwork, workplace friendship, and workplace loneliness variables, which are thought to affect emotional commitment to change, which means voluntary and willing participation of employees in the change process, were discussed within the scope of the research.

According to the findings, it has been determined that the employees' negative perceptions towards the change process, perception of being not ready for the change, and their concerns that the change will affect them negatively are important variables affecting the voluntary and willing participation in the change processes. Bareil (2013) emphasized that high levels of anxieties about change lead to higher employees' resistance. Also, Malik and Garg (2017) stated that creating a learning culture and knowledge sharing structure directs employees to develop affective commitment to change.

Weiner, Amick \& Lee (2008) state that organizational readiness refers to organizational members' change commitment and change efficacy to implement organizational change. In this context, it defines the concept of readiness for change as a whole that should be handled together with the commitment to change and change effectiveness (Weiner, 2009). Lehman, Greener \& Simpson (2002) emphasize considering some factors in change processes such as level of motivation for change, institutional resources, personality attributes of the staff, and organizational climate. Considering that change processes can cause emotional effects on employees and physical aspects, it is essential that employees feel ready for the process and develop an awareness that change will not have negative consequences for them. With the introduction of changes should be encouraged debate and discussion about the need and importance of them. Data presentation can help create a sense of the importance of the application changes. Information and results of a sample implementation of changes may change the approach to be applied during the actual implementation. The purpose of the sample application changes must be explained to all the organization's members and stakeholders (Ionescu, Meruță \& Dragomiroiu, 2014, p. 295). Buick et al. (2018) stated that managers who are actively engaged change agents, who frame and make sense of the change with employees, can reduce resistance. However, for this to be realized, organizations need to actively support the systematic development of middle management change management capabilities.

Another variable that affects affective commitment to change is emotional deprivation, defined as the level of perception of the emotional quality of relationships at work. It has been determined that employees feel excluded, disconnected, and emotionally distant in their relationships at work hurts the individual's commitment to business during change processes. Studies indicate that meeting the need for relationship and belonging (Blatt, 2008), especially within the organizational context, is an issue that should be considered for the general well-being of the individual (Heaphy and Dutton, 2008). Considering the amount of natural and observable relationships of an employee's experiences and the perceived quality and satisfaction of these relationships, it is arguably one of the essential factors in loneliness in the workplace (Wright and Sillard, 2020). They meet the individual's emotional support 
needs, whose anxiety and stress level increases, especially during the change processes, is essential for the individual to adapt to the process. Ayazlar and Güzel (2014) state that employees' emotional deprivation in their work relationships is an important variable that also affects their affective commitment to the company. Ouedraogo and Ouakouak (2018) also stated that providing a solid communication system is vital for change success.

As a result of the analyses, other variables (communion striving, participative safety, workplace friendship, and social companionship) on affective commitment to change could not be statistically confirmed. However, it is thought that significant results can be obtained as a result of testing the same variables in organizations with different structures, cultures, and climates. Although each change process has various characteristics in terms of its content, it should not be overlooked that the active participation of the employees in the process, the correct explanation of the need for change, and the taking into account the emotional and cognitive aspects of the process along with the physical elements. Although all developments have prompted humanity to evolve and change digitally, it is one of the primary duties of those who manage the change process to understand the human in need of nutrition with its emotional and spiritual aspects and explain that he is a part of the change.

The impact of the pandemic process on organizations can also be considered in this context. In the studies conducted, it is seen that the COVID-19 pandemic process forces institutions to consider some topics such as workload (Politi \& Balzarini, 2020), knowledge management (Barnes, 2020), crisis management (Mirvis, 2020) learning processes (Mishra, Gupta \& Shree, 2020). In this context, the research findings provide useful information to companies that are in the process of change or understand that they have to change.

\section{Peer-review:}

Externally peer-reviewed

\section{Conflict of interests:}

The author(s) has (have) no conflict of interest to declare.

\section{Grant Support:}

The authors declared that this study has received no financial support.

\section{Acknowledgement:}

Special thanks to all staff and managers affiliated with the Yozgat Provincial Health Directorate for their contribution and support.

\section{References}

Abele, A. E., \& Wojciszke, B. (2007). Agency and communion from the perspective of self versus others. Journal of Personality and Social Psychology 93(5):751-63, 93(5), 751-763.

Altındiş, M., Altındiş, S., \& Saylı, H. (2011). Sağlık profesyonellerinin değişim sürecindeki tutumlarını belirlemeye yönelik bir araştırma. Uluslararası Yönetim İktisat ve İşletme Dergisi, 7(14), 75-93.

Altunışık, R., Coşkun, R., Bayraktaroğlu, S., \& Yıldırım, E. (2015). Sosyal Bilimlerde Araştırma Yöntemleri. 9. Baskı. Sakarya: Sakarya Yayıncilık.

Altunışık, R., Coşkun, R., Bayraktaroğlu, S., \& Yıldırım, E. (2007). Sosyal Bilimlerde Araştırma YöntemleriSPSS Uygulamalı. 5. Baskı. Sakarya: Sakarya Yayıncilık.

Anderson, N. R., \& West, M. A. (1998). Measuring climate for work group innovation: development and validation of the team climate inventory. Journal of Organizational Behaviour(19), 235-258.

Armenakis, A. A., Harris, S. G., \& Mossholder, K. W. (1993). Creating Readiness for Organizational Change. Human Relations, 46(6), 681-704.

Ayazlar, G., \& Güzel, B. (2014). The Effect of Loneliness in the Workplace on Organizational Commitment. Procedia - Social and Behavioural Sciences(131), 319-325. 
Baker, D. P., Day, R., \& Salas, E. (2006). Teamwork as an Essential Component of High-Reliability Organisations. Health Research and Educational Trust, 42(4p2), 1576-1598.

Bareil, C. (2013). Two paradigms about resistance to change. Organization Development Journal, 31(3), 5971.

Barnes, S. J. (2020). Information management research and practice in the post-COVID-19 world. International Journal of Information Management, 55, 102175.

Barrick, M. R., Stewart, G. L., \& Piotrowski, M. (2002). Personality and job performance: test of the mediating effects of motivation among sales representatives. J Appl Psychol., 87(1), 43-51.

Bell, S. T. (2007). Deep-Level Composition Variables as Predictors of Team Performance:A MetaAnalysis. Journal of Applied Psychology, 92(3), 595-615.

Berman, E. M., West, J. P., \& RichterJr., M. N. (2002, April). Workplace Relations: Friendship Patterns and Consequences (According to Managers). Public Administration Review, 62(2), 217-230.

Biçer, C., \& Büyükyılmaz, O. (2019). The Effect of Perceptions of Organizational Politics on Workplace Friendship. Uluslararası Yönetim İktisat ve İşletme Dergisi, 15(2), 515-531.

Blatt, S.J. (2008). Polarities of Experience: Relatedness and Self-definition in Personality Development, Psychopathology, and the Therapeutic Process. Washington, DC: American Psychological Association Press.

Bovey, W. H., \& Hede, A. (2001). Resistance to organisational change: The role of defence mechanisms. Journal of Managerial Psychology, 16(7), 534-548.

Buick, F., Blackman, D., \& Johnson, S. (2018). Enabling middle managers as change agents: Why organisational support needs to change. Australian Journal of Public Administration, 77(2), 222-235.

Byrne, B. M. (2010). Structural equation modeling with AMOS: Basic concepts, applications, and programming. New York: Routledge.

Campion, M. A., Medsker, G. J., \& Higgs, A. C. (1993). Relations Between Work Group Characteristics and Effectiveness: Implications for Designing Effective Work Groups. Personnel Psychology(43), 823848.

Coch, L., \& French, J. R. (1948). Overcoming resistance to change. Human Relations, 1(4), 512-532.

Cohen, S. G., \& Bailey, D. E. (1997). What makes teams work: Group effectiveness research from the shop floor to the executive suite. Journal of Management, 23(3), 239-290.

Connor, P. E., \& Lake, L. K. (1988). Managing organisational change. New York : Praeger.

Çalışkan, S. C. (2011). Çalışanların Psikolojik Güçlendirilme Algıları Üzerinde İşyeri Arkadaşlıkları Ve Örgütsel İletişimin Etkisi. Çukurova Üniversitesi Sosyal Bilimler Enstitüsü Dergisi, 20(3), 77-92.

D'aveni, R. A., \& Dagnino, G. B. (2010). The Age of Temporary Advantage. Strategic Management Journal, 31, 1371-1385.

De Jong, B. A., \& Elfring, T. (2010). How Does Trust Affect the PErformance of Ongoing Teams? The Mediating Role of Reflexivity, Monitoring and Effort. Academy of Management Journal, 53(3), 535-549.

Devine, D. J., Clayton, L. D., Philips, J. L., Dunford, B. B., \& Melner, S. B. (1999, December). Teams in Organisations: Prevalence, Characteristics, and Effectiveness. Small Group Research, 30(6), 678-711.

Doğan, T., Çetin, B. \& Sungur, M.Z. (2009). İş Yaşamında Yalnızlık Ölçeği Türkçe formunun geçerlilik ve güvenilirlik çalışması. Anadolu Psikiyatri Dergisi, 10: 271-277.

Ergün, E., \& Eyisoy, M. E. (2018). Takım Çalışması Özelliklerinin Takım Performansına Etkisi Üzerine Bir Araştırma. Business Management Studies: An International Journal, 6(4), 1455-1475.

Ertosun, Ö. G., \& Erdil, O. (2013). The Effects of Loneliness on Employees' Commitment and Intention to Leave . Procedia - Social and Behavioural Sciences , 469-476.

Erwin, D. G., \& Garman, A. N. (2010). Resistance to organisational change: linling research and practice. Leadership \& Organization Development Journal, 31(1), 39-56.

Fedor, D. B., Caldwell, S., \& Herold, D. M. (2006). The Effects of Organisational Changes on Empmloyee Commitment: A Multi-Level Investigation. Personnel Psychology, 59(1). 
Fjellstedt, L. (2015). Examining Multidimensional Resistance of Organizational Change: A Strong Structuration Approach. Unpublished PhD. Thesis. United States of America: Graduate School of Education and Human Development of The George Washington University .

Ghorbanhosseini, M. (2013). The Effect of Organizational Culture, Teamwork and Organizaitonal Development on Organizational Commitment: The Mediating Role of Human Capital. Tehnicki vjesnik, 20(6), 1019-1025.

Green, V. A., \& Wildermuth, N. L. (1993). Self-focus, other-focus, and interpersonal needs as correlates of loneliness. Psychological Reports, 73(3 (Pt1)), 843-850.

Guzzo, R. A., \& Dickson, M. W. (1996). Teams In Organisations: Recent Research on Performance and Effectiveness. Annu. Rev. Psychol(47), 307-338.

Hair, J., Black, W. C., Babin, B. J. \& Anderson, R. E. (2010) Multivariate data analysis (7th ed.). Upper Saddle River, New Jersey: Pearson Educational International.

Hakanen, M., \& Häkkinen, M. (2015). Trust in building high-performing teams - conceptual approach. Electronic Journal of Business Ethics and Organization Studies, 20(2), 43-53.

Hannan, M. T., \& Freeman, J. (1977). The population ecology of organisations. American journal of sociology, 82(5), 929-964.

Heaphy, E. \& Dutton, J. (2008). Positive social interactions and the human body at work: Linking organisations and physiology. Academy of Management Review, 33(1), 137-162.

Herscovitch, K., \& Meyer, J. P. (2002). Commitment to Organizational Change: Extension of a ThreeComponent Model. Journal of Applied Psychology, 87(3), 474-487.

Herscovitch, L. (2003). Resistance to Organizational Change: Toward A Multidimensional Conceptualisation. University of Western Ontario London, Ontario-Canada.

Hogan, R., \& Shelton, D. (1998). A Socioanalytic Perspective on Job Performance. Human Performance, 11(2), 129-144.

Huang, S.P. (2016). A study on the effects of emotional intelligence and workplace friendship on job satisfaction and performance of employees in micro-enterprises. Journal of Interdisciplinary Mathematics, 19(3), 567-583.

Huy, N. Q. (2002). Emotional balancing of organisational continuity. Administrative Science Quarterly(47), 31-69.

Iliyas, M. (2016). İşyeri Arkadaşlık Fırsatları ve İş Çıktıları Arasındaki İlişkiler ve Bu İlişkilerde Birlik Çabası Motivasyonunun Rolü. Yüksek Lisans Tezi. Marmara Üniversitesi, SBE, İstanbul.

Ionescu, E. I., Meruță, A., \& Dragomiroiu, R. (2014). Role of managers in management of change. Procedia Economics and Finance, 16, 293-298.

Isabella, L. A. (1990). Evolving Interpretations as a Change Unfolds: How Managers Contrue Key Organizational Events. Academy of Management Journal, 33(1), 7-41.

Işık, M. (2014). Çă̆rı Merkezlerinde Takım Çalışması ve Örgütsel Güven İlişkisi. Yüksek Lisans Tezi. Atatürk Üniversitesi, SBE, Erzurum.

Karagöz, Y. (2014). SPSS 21.1 Uygulamalı Biyoistatistik. Ankara: Nobel Akademik Yayıncılık.

Koçel, T. (2005). İşletme Yöneticiliği. 10. Baskı, İstanbul: Arıkan Yayınları.

Lehman, W. E., Greener, J. M., \& Simpson, D. D. (2002). Assessing organisational readiness for change. Journal of substance abuse treatment, 22(4), 197-209.

Malik, P., \& Garg, P. (2017). The relationship between learning culture, inquiry and dialogue, knowledge sharing structure and affective commitment to change. Journal of Organizational Change Management, 30(4), 610-631.

Marangoni, C., \& Ickes, W. (1989). Loneliness: A Theoretical Review with Implications for Measurement. Journal of Social and Personal Relationships, 6(93), 93-128.

Meyer, J. P., \& Allen, N. J. (1997). Commitment in the Workplace: Theory, Research, and Application. Thousand Oaks, CA: Sage Pub. 
Mirvis, P. (2020). Reflections: US Coronavirus Crisis Management--Learning from Failure Donald Trump and More, January-April, 2020. Journal of Change Management.

Mishra, L., Gupta, T., \& Shree, A. (2020). Online teaching-learning in higher education during lockdown period of Covid-19 pandemic. International Journal of Educational Research Open, 100012.

Morrison, R., \& Cooper-Thomas, H. (2015). Friendship among co-workers. I. M. (Eds.) içinde, Friendship Among Coworkers. (s. New York ). Oxford University Press.

Mowday, R. T., Steers, R. M., \& Porter, L. W. (1979). The measurement of organisational commitment. Journal of Vocational Behaviour, 14(2), 224-247.

Ng, T. W., \& Lucianetti, L. (2015). Goal striving, idiosyncratic deals, and job behaviour. Journal of Organizational Behaviour(37), 41-60.

Nielsen, I. K., Jex, S. M., \& Adams, G. A. (2000). Development and validation of scores on a twodimensional workplace friendship scale. Educational and Psychological Measurement, 60(4), 628-643.

Nohe, C., Michaelis, B., Menges, J. I., Zhang, Z., \& Sonntag, K. (2013). Charisma and Organizational Change: A multi level study of perceived charisma, commitment to change and team performance. The Leadership Quarterly(24), 378-389.

Ouedraogo, N., \& Ouakouak, M. L. (2018). Impacts of personal trust, communication, and affective commitment on change success. Journal of Organizational Change Management, 31(3), 676-696.

Özbek, M. F. (2018). Do We Need Friendship in the Workplace? The Theory of Workplace Friendship and Employee Outcomes: The Role of Work Ethics. Journal of Economy Culture and Society, 153-176.

Perlman, D., \& Peplau, L. A. (1981). Theoretical approaches to loneliness. L. A. (eds) içinde, Loneliness: A Sourcebook of Current Theory, Research, and Therapy (32-56). New York: Wiley-Interscience.

Politi, L. S., \& Balzarini, L. (2020). The radiology department during the COVID-19 pandemic: a challenging, radical change. European Radiology, 1.

Rafferty, A. E., \& Jimmieson, N. L. (2017). Subjective Perceptions of Organizational Change and Employee Resistance to Change: Direct and Mediated Relationships with Employee Well-being. British Journal of Management(28), 248-264.

Seçkin, Z., Demirel, Y. \& Özçınar, M.F. (2016). Örgütsel Değişim Sürecinin Algılanmasına Yönelik Betimsel Bir Araştırma. Aksaray Üniversitesi İktisadi ve İdari Bilimler Fakültesi Dergisi, 8(1), 125-134.

Shum, P., Bove, L., \& Auh, S. (2008). Employees' affective commitment to change:The key to successful CRM implementation;. European Journal of Marketing, 42(11/12), 1346-1371.

Sias, P. M., Smith, G., \& Avdeyeva, T. (2009). Sex and sex-composition differences and similarities in peer workplace friendship development. Communication Studies, 54(3), 322-340.

Straub, J. T. (2002). Ekip Kurma ve Yönetme (Çev: Savaş Şenel). İstanbul: Hayat Yayıncıllk.

Tavakoli, M. (2014). A Cognitive Model of Positive Organizational Change. Journal of Management Policies and Practices, 2(1), 11-25.

Todnem, R., Kuipers, B., \& Procter, S. (2018). Understanding Teams in Order to Understand Organizational Change: The OTIC Model of Organizational Change. Journal of Change Management, 18(1), 1-9.

Toprak, M. \& Aydın, T. (2015). Değişime Bağlılık Ölçeğinin Türkçeye Uyarlanması Çalışması. Electronic International Journal of Education, Arts, and Science, 1(1), 35-54.

Ural, A. \& Kılıç, İ. (2005). Bilimsel Araştırma Süreci Ve SPSS İle Veri Analizi: SPSS 12.0 For Windows. Ankara: Detay Yayıncılık.

Wanberg, C. R., \& Banas, J. T. (2000). Predictors and Outcomes of Openness to Changes in Reorganizing Workplace. Journal of Applied Psychology, 85(1), 132-142.

Weick, K. E., \& Quinn, R. E. (1999). Organizational Change and Development. Annual Review of Psychology(50), 361-386.

Weiner, B. J. (2009). A Theory of Organizational Readiness. Implementation Science. 4(67), 1-9. 
Weiner B.J., Amick H. \& Lee S.Y. (2008). Conceptualisation and measurement of organisational readiness for change: a review of the literature in health services research and other fields. Med Care Res Rev, 65, 379-436

Wiggins, J. S., \& Trapnell, P. D. (1996). A dyadic-interactional perspective on the five-factor model. J. S. Wiggins içinde, The five-factor model of personality: Theoretical perspectives (88-162). Guilford Press.

Wilson, D. S. (2010). Perceptions of Organizational Change and The Relationship to Organizational Outcomes. Unpublished Ph.D Thesis . United States of America: Faculty of Graduate School of Saint Louis University.

Wright, S. L. (2005). Loneliness in the Workplace . University of Canterbury (Unpublished PhD. Thesis.

Wright, S., \& Silard, A. (2020). Unravelling the antecedents of loneliness in the workplace. Human Relations, 0018726720906013.

Wright, S. L., Burt, C. D., \& Strongman, K. T. (2006). Loneliness in the Workplace: Construct definition and scale development. New Zealand Journal of Psychology, 35(2), 59-68.

Yıldız, D. \& Uzunsakal, E. (2018). Alan Araştırmalarında Güvenilirlik Testlerinin Karşılaştırılması Ve Tarımsal Veriler Üzerine Bir Uygulama. Uygulamalı Sosyal Bilimler Dergisi, 2(1), 14-28.

Yılmaz, H. (1999). İşletmelerde Takım Çakışması Yoluyla Motivasyon. Standart Dergisi, Nisan, 38, $28-33$. 